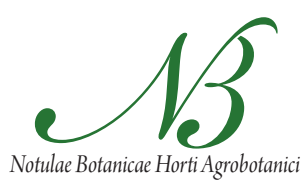

Cluj-Napoca

\title{
The Influence of Weather Conditions During Vegetation Period on Yielding of Twelve Determinate Tomato Cultivars
}

\author{
ElżbietaJĘDRSZCZYK ${ }^{* *}$, BarbaraSKOWERA²,Joanna KOPCIŃSKA, Anna M. AMBROSZCZYK' \\ ${ }^{1}$ Agricultural University, Department of Vegetable and Medicinal Plants, Faculty of Horticulture, al. 29Listopada \\ 54,31-425 Kraków,Poland; e.jedrszczyk@ogr.ur.krakow.pl ("correspondingauthor) \\ ${ }^{2}$ Agricultural University, Department of Applied Mathematics, Department of Environmental \\ Engineering and Land Surveying, al. Mickiewicza 24/28, 30-059 Kraków, Poland \\ ${ }_{3}^{3}$ Agricultural University, Department of Ecology, Climatology and Air Protection, Department of Environmental \\ Engineering and Land Surveying, al. Mickiewicza 24/28, 30-059 Kraków, Poland
}

\begin{abstract}
Tomato yield and biomass growth are closely linked to climatic conditions during vegetation period. Low temperatures and high precipitation in summer constitute the main cause of the large variability of field tomato yielding contributing to worsen the quality of the yield. The aim of the investigation was determining the influence of meteorological basic components in the growing season of the tomato to total and marketable yield of twelve determinate cultivars. Experiment took place in the open field in the Vegetable Experimental Station of Agricultural University of Mydlniki near Cracow in the years 2008 - 2010. A different sensitivity of examined tomato cultivars to the course of weather conditions was stated. 'Ondraszek' cultivar get the highest marketable yield in all years of investigation what indicate the most adaptation to variable weather conditions and cultivars 'Hetman', 'Hubal' and 'Babinicz' were the least adaptated and they gave the lowest yield. Analysis of the influence of weather condition on total and marketable yield of twelve determine tomato cultivars showed, that the sum and distribution of precipitation were decisive. High precipitations decreased total and marketable yield, whereas frequent and lower precipitations influenced favorable. Since from the third stage, i.e., the beginning of fruits setting to the beginning of ripening, a larger impact of meteorological factors on marketable than total yield had been observed. In the fruits ripening stage a marketable yield depended only on sum of temperatures.
\end{abstract}

Keywords: hydrothermal index, open field cultivation, precipitation, temperature

\section{Introduction}

Tomato yield and biomass growth are closely linked to environmental and climatic conditions (Kascjan Maršic et al., 2005; Konys, 1990). In the open field their geographic distribution are limited by sensitivity to low temperatures.

Cultivation areas for determinate tomatoes are often located in the climatic favorably Mediterranean region. According to Konys (1990) in years with climatic condition favorable for tomato yield ranged from 14-15 t.ha ${ }^{-1}$, in worse only to 5-7 t.ha ${ }^{-1}$. Konys (1990) observed that only in favorable conditions, traditional growing methods gave good results and increased yield.

Poland is the furthest north country in Europe, where tomato is grown in an open field on a production scale. Low temperatures and high precipitation in summer constitute the main cause of the large variability of field tomato yielding contributing to worsen the quality of the yield (Kascjan Maršic et al., 2005).

Depending on the species and the developmental stage meteorological elements have a differential impact to the height and the quality of yield of crop plants (Kalbarczyk, 2006; Kałużewicz et al., 2010; Licznar-Maleńczuk, 2004; Samborski, 2006; Skowera et al., 2007; Skowera and Kołodziej, 2003). This impact is included in the statistical modeling for numerous vegetable plants, including tomatoes (Kalbarczyk, 2010; Voican et al., 1995). In south Europe, in countries of Mediterranean region, the model tests concerning regionalization of the arable farming of the tomato, were being conducted by Voican et al. (1995). They confirm, that the crucial factors affected yield are environmental conditions, in particular weather conditions (the solar radiation, the air temperature and precipitation).

In conditions of the moderate climate, being characterized by a large temporal and spatial variability, the cultivar selection is a main element deciding about getting the satisfying yield (Bandurska et al., 2011; Kascjan Maršic et al., 2005).

In the growing season in Poland a big diversification of precipitation is observed, whereas thermal condition is smaller. In last years changes in the structure of precipitation and an increase in the frequency of extreme 
204

pluviothermal conditions are being observed (Bokwa and Skowera, 2009; Skowera and Wojkowski, 2003). In Poland numerous cultivars of determinate tomato are being used and therefore pointing out those genotypes, which are more resistant to climatic condition stress, will contribute to the profitability of the cultivation.

The aim of the investigation was determining the influence of meteorological basic components in the growing season of the tomato to total and marketable yield of twelve determinate cultivars.

\section{Material and methods}

Experiment took place in the open field in the Vegetable Experimental Station of Agricultural University of Mydlniki near Cracow in the years 2008 - 2010 on the brown soil. A completely randomized block design with four replicates and 40 plants for plot were used. Dates of sowing and seedlings planting in years were following: 2008 - April 8 sowing, planting 16 May, 2009 - April 16 sowing, planting 21 May, 2010 - March 31 sowing, planting 26 May. Plants spacing was $80 \times 60 \mathrm{~cm}$. During the growing season typical treatments, as weeding and chemical diseases protection, were carried out according to current recommendations.

During vegetation period detailed observation of developmental stages of tomato plant were done. Terms of beginning of flowering, fruit setting and fruit ripening and term of harvesting were noted. Harvesting was performed once, at the stage of maturity of individual cultivar. The yield ( $\mathrm{kg} /$ per plant) and its structure was calculated. Number of days $(\mathrm{L})$ and sum of precipitation $(\mathrm{P})>0.1 \mathrm{~mm}$ and also sum of temperature $\left(\sum \mathrm{t}\right)>0^{\circ} \mathrm{C}$ were calculated. These data were measured by automatic meteorological station installed on experimental plots.

Average monthly air temperatures and sums of precipitation in investigated years were compared to multiannual means 1961-1990 (Kossowska-Cezak et al., 2000).

In order to analyzing meteorological conditions on tomato developmental stages Sielianinow's hydrothermal index $(\mathrm{K})$ were used. $\mathrm{K}$ is known as a co-efficient of provision plant in water. The index is computed as follows:

$$
\mathrm{K}=\mathrm{P} / 0.1 \sum \mathrm{t}
$$

where: $\mathrm{P}$ is sum of monthly precipitation in $\mathrm{mm} . \sum \mathrm{t}$ is sum of daily mean air temperatures $>0^{\circ} \mathrm{C}$. Skowera and Wojkowski (2003) cited nine classes of the hydrothermal index $\mathrm{K}$ :

$\begin{array}{lll}\text { extremely dry } & \text { (ss) } & \mathrm{K} \leq 0.4 \\ \text { very dry } & \text { (bs) } & 0.4<\mathrm{K} \leq 0.7 \\ \text { dry } & \text { (s) } & 0.7<\mathrm{K} \leq 1.0 \\ \text { relatively dry } & \text { (ds) } & 1.0<\mathrm{K} \leq 1.3 \\ \text { optimal } & \text { (o) } & 1.3<\mathrm{K} \leq 1.6 \\ \text { relatively humid } & \text { (dw) } & 1.6<\mathrm{K} \leq 2.0 \\ \text { humid } & \text { (w) } & 2.0<\mathrm{K} \leq 2.5 \\ \text { very humid } & \text { (bw) } & 2.5<\mathrm{K} \leq 3.0 \\ \text { extremely humid } & \text { (sw) } & \mathrm{K}>3.0\end{array}$

Analysis of the total and marketable yield of examine cultivars were based on the Duncan test.

The statistical dependence of the total yield and marketable yield of tomato plants from meteorological elements were analyzed. Taking into account length of developmental stages. A general model for the multiple regression (forward selection) predicted total and marketable yield were proposed.

Total yield $=b_{0}+b_{1} \cdot$ sum of temperature $+b_{2}$ sum of precipitation $+b_{3}$ number of days with precipitation;

Marketable yield $=b_{0}+b_{1}$ sum of temperature $+b_{2}$ sum of precipitation $+b_{3}$ number of days with precipitation.

In the first step the variable with the highest impact on tomato yield (the highest squared correlation) was added to the regression equation. Next the partial F statistic for each possible remaining variable was computed and if the variable with the highest $F$ statistic passed a criterion $(\alpha=0.05)$, it was added to the regression equation. Then, it was checked whether the variable in the regression equation passed the criterion for significance. If so, they remained in the equation, otherwise they were removed from the equation. The procedure went on until no variable that passed the criterion for significance could be found. The calculation were made in the Statistica 10.

\section{Results and discussion}

Meteorological conditions during vegetation in investigated years 2008-2010 were diversified very much and

Tab. 1. Mean monthly air temperature and sum of precipitation during vegetation period 2008-2010 on based of multiannual means 1961-1990 (Kraków-Balice)

\begin{tabular}{|c|c|c|c|c|c|c|}
\hline Years & Meteorological factors & May & June & July & August & September \\
\hline \multirow{2}{*}{ Period 1961-1990 } & $\mathrm{t}$ & 13.1 & 16.2 & 17.5 & 16.9 & 13.7 \\
\hline & $\mathrm{p}$ & 83.0 & 97.0 & 85.0 & 87.0 & 54.0 \\
\hline \multirow{2}{*}{2008} & $\mathrm{t}$ & 13.7 & 18.5 & 18.8 & 18.2 & 12.6 \\
\hline & $\mathrm{p}$ & 25.9 & 26.9 & 144.0 & 42.9 & 98.8 \\
\hline \multirow{2}{*}{2009} & $t$ & 13.5 & 16.0 & 19.9 & 18.7 & 15.1 \\
\hline & $\mathrm{p}$ & 97.8 & 140.2 & 82.6 & 53.1 & 35.0 \\
\hline \multirow{2}{*}{2010} & $\mathrm{t}$ & 12.8 & 17.5 & 20.7 & 18.4 & 12.1 \\
\hline & $\mathrm{p}$ & 299.0 & 135.1 & 105.2 & 127.5 & 116.3 \\
\hline
\end{tabular}

t-temperature $\left({ }^{\circ} \mathrm{C}\right)$, p- sum of precipitation $(\mathrm{mm})$ 
they modified the tomato height and a development in individual stage (Tab. 1 and 2). Many authors observed this influence (Abdul-Baki et al., 1996; Kascjan Maršic et al., 2005; Konys, 1990). Even in the Mediterranean region, which is regarded as the most climatically supporting the cultivation of the industrial tomato, a dependence of yielding on the course of the weather is noticed (Kascjan Maršic et al., 2005).
205

Variability of weather conditions is illustrated by average monthly air temperatures and sums of precipitation on based of multiannual means 1961-1990 (Tab. 1.) and also enclosed in the Tab. 2 calculated climatic indicators, i.e. Sielianinow's hydrothermal index $(\mathrm{K})$ and the number of days with precipitation (L). Sielianinow's hydrothermal index higher than 1.6 determines excessively humid conditions, whereas 1.0 to 1.6 indicates relatively

Tab. 2. Sielianinow hydrotermal index value $(K)$ and number of days of precipitation $(\mathrm{L})$ during succeeding developmental stages

\begin{tabular}{|c|c|c|c|c|c|c|c|c|c|}
\hline \multirow{3}{*}{ Cultivar } & \multirow{3}{*}{ Year } & \multicolumn{8}{|c|}{ Developmental stage } \\
\hline & & \multicolumn{2}{|c|}{$1^{*}$} & \multicolumn{2}{|c|}{2} & \multicolumn{2}{|c|}{3} & \multicolumn{2}{|c|}{4} \\
\hline & & $\mathrm{K}$ & $\mathrm{L}$ & $\mathrm{K}$ & $\mathrm{L}$ & $\mathrm{K}$ & $\mathrm{L}$ & $\mathrm{K}$ & $\mathrm{L}$ \\
\hline \multirow{3}{*}{ 'Sokal F' } & 2008 & 0.5 & 9 & 0.4 & 5 & 1.8 & 20 & 0.8 & 10 \\
\hline & 2009 & 2.7 & 14 & 4.5 & 10 & 1.3 & 18 & 0.3 & 6 \\
\hline & 2010 & 3.9 & 6 & 1.2 & 11 & 1.6 & 20 & 2.1 & 7 \\
\hline \multirow{3}{*}{ 'Batory $F_{1}$ ' } & 2008 & 0.5 & 9 & 0.7 & 7 & 2.4 & 18 & 0.8 & 9 \\
\hline & 2009 & 2.6 & 15 & 4.9 & 9 & 1.0 & 18 & 1.6 & 7 \\
\hline & 2010 & 2.1 & 6 & 1.5 & 10 & 1.8 & 15 & 2.1 & 7 \\
\hline \multirow{3}{*}{ 'Rejtan $\mathrm{F}_{1}$ ' } & 2008 & 0.5 & 9 & 0.7 & 7 & 2.0 & 18 & 0.9 & 9 \\
\hline & 2009 & 2.3 & 17 & 3.0 & 15 & 0.8 & 15 & 2.3 & 3 \\
\hline & 2010 & 4.3 & 6 & 1.2 & 11 & 1.6 & 20 & 2.2 & 4 \\
\hline \multirow{3}{*}{ 'Hetman' } & 2008 & 0.6 & 10 & 0.7 & 6 & 2.0 & 18 & 1.3 & 7 \\
\hline & 2009 & 2.1 & 18 & 3.2 & 14 & 0.8 & 15 & 2.5 & 6 \\
\hline & 2010 & 3.3 & 9 & 1.0 & 8 & 1.6 & 20 & 2.1 & 7 \\
\hline \multirow{3}{*}{ 'Lubań' } & 2008 & 0.5 & 9 & 0.7 & 7 & 2.3 & 18 & 0.8 & 10 \\
\hline & 2009 & 2.6 & 20 & 2.8 & 12 & 0.9 & 12 & 1.2 & 6 \\
\hline & 2010 & 4.3 & 6 & 1.2 & 11 & 1.7 & 16 & 2.2 & 6 \\
\hline \multirow{3}{*}{ 'Babinicz' } & 2008 & 0.6 & 9 & 0.6 & 2 & 1.2 & 11 & 1.6 & 19 \\
\hline & 2009 & 2.8 & 12 & 3.2 & 15 & 1.0 & 17 & 1.5 & 6 \\
\hline & 2010 & 4.3 & 6 & 1.5 & 10 & 1.7 & 12 & 1.8 & 11 \\
\hline \multirow{3}{*}{ 'Awizo $F_{1}^{\prime}$} & 2008 & 0.5 & 9 & 0.7 & 7 & 2.0 & 18 & 1.1 & 7 \\
\hline & 2009 & 2.3 & 17 & 3.2 & 11 & 1.0 & 18 & 1.6 & 4 \\
\hline & 2010 & 4.8 & 6 & 1.1 & 11 & 1.6 & 19 & 1.8 & 5 \\
\hline \multirow{3}{*}{ 'Mieszko $F_{1}$ ' } & 2008 & 0.5 & 9 & 0.7 & 7 & 2.0 & 18 & 0.8 & 10 \\
\hline & 2009 & 2.7 & 14 & 3.5 & 13 & 0.9 & 16 & 1.9 & 6 \\
\hline & 2010 & 3.9 & 6 & 1.2 & 11 & 1.7 & 21 & 1.8 & 6 \\
\hline \multirow{3}{*}{ 'III A F } & 2008 & 0.6 & 9 & 0.6 & 2 & 1.5 & 21 & 1.1 & 12 \\
\hline & 2009 & 2.6 & 15 & 2.9 & 13 & 1.0 & 18 & 1.3 & 6 \\
\hline & 2010 & 4.3 & 6 & 1.2 & 11 & 1.8 & 13 & 1.9 & 9 \\
\hline \multirow{3}{*}{ 'Ondraszek' } & 2008 & 0.5 & 9 & 0.8 & 2 & 2.0 & 16 & 1.4 & 9 \\
\hline & 2009 & 2.4 & 16 & 2.9 & 13 & 1.0 & 17 & 1.5 & 4 \\
\hline & 2010 & 4.8 & 6 & 1.2 & 11 & 1.8 & 13 & 1.5 & 4 \\
\hline \multirow{3}{*}{ 'Hubal' } & 2008 & 0.6 & 10 & 0.6 & 6 & 2.0 & 18 & 0.9 & 9 \\
\hline & 2009 & 2.5 & 16 & 3.8 & 11 & 1.1 & 15 & 0.5 & 4 \\
\hline & 2010 & 4.3 & 6 & 1.2 & 11 & 1.7 & 15 & 1.7 & 8 \\
\hline \multirow{3}{*}{ 'Talon' } & 2008 & 0.5 & 9 & 0.4 & 5 & 1.8 & 20 & 1.1 & 7 \\
\hline & 2009 & 2.7 & 13 & 4.5 & 10 & 1.0 & 19 & 1.7 & 7 \\
\hline & 2010 & 3.1 & 9 & 1.2 & 9 & 1.7 & 18 & 1.6 & 3 \\
\hline \multirow{3}{*}{ Mean } & 2008 & 0.6 & 9.2 & 0.6 & 5.3 & 1.9 & 17.8 & 1.0 & 9.8 \\
\hline & 2009 & 2.5 & 15.6 & 3.4 & 12.2 & 1.0 & 16.5 & 1.4 & 5.4 \\
\hline & 2010 & 3.9 & 6.5 & 1.2 & 10.4 & 1.7 & 16.8 & 1.9 & 6.8 \\
\hline
\end{tabular}

1. Planting-beginning of flowering, 2. Beginning of flowering-beginning of fruits setting, 3. Beginning of fruits setting-beginning of ripening, 4. Beginning of ripeningharvest 
Tab. 3. The length of succeeding developmental stages (days)

\begin{tabular}{|c|c|c|c|c|c|c|}
\hline \multirow{2}{*}{ Cultivar } & \multirow{2}{*}{ Year } & \multicolumn{4}{|c|}{ Developmental stage } & \multirow{2}{*}{$\begin{array}{c}\text { Vegatation } \\
\text { period }^{* *}\end{array}$} \\
\hline & & $1^{*}$ & 2 & 3 & 4 & \\
\hline \multirow{3}{*}{ 'Sokal F' } & 2008 & 25 & 10 & 42 & 39 & 116 \\
\hline & 2009 & 21 & 14 & 35 & 22 & 92 \\
\hline & 2010 & 15 & 24 & 42 & 12 & 93 \\
\hline \multirow{3}{*}{ 'Batory $\mathrm{F}_{1}$ ' } & 2008 & 25 & 17 & 31 & 38 & 111 \\
\hline & 2009 & 22 & 13 & 46 & 15 & 96 \\
\hline & 2010 & 12 & 19 & 40 & 11 & 82 \\
\hline \multirow{3}{*}{ 'Rejtan F' } & 2008 & 25 & 17 & 35 & 34 & 111 \\
\hline & 2009 & 26 & 24 & 39 & 7 & 96 \\
\hline & 2010 & 14 & 24 & 46 & 8 & 92 \\
\hline \multirow{3}{*}{ 'Hetman' } & 2008 & 27 & 15 & 35 & 10 & 87 \\
\hline & 2009 & 28 & 22 & 39 & 12 & 101 \\
\hline & 2010 & 19 & 20 & 42 & 12 & 93 \\
\hline \multirow{3}{*}{ 'Lubań' } & 2008 & 25 & 17 & 31 & 43 & 116 \\
\hline & 2009 & 31 & 19 & 33 & 15 & 98 \\
\hline & 2010 & 14 & 23 & 35 & 10 & 82 \\
\hline \multirow{3}{*}{ 'Babinicz' } & 2008 & 24 & 9 & 23 & 40 & 96 \\
\hline & 2009 & 18 & 22 & 43 & 12 & 95 \\
\hline & 2010 & 14 & 20 & 31 & 17 & 64 \\
\hline \multirow{3}{*}{ 'Awizo $F_{1}^{\prime}$} & 2008 & 25 & 17 & 34 & 19 & 95 \\
\hline & 2009 & 26 & 20 & 41 & 10 & 79 \\
\hline & 2010 & 13 & 25 & 41 & 10 & 89 \\
\hline \multirow{3}{*}{ 'Mieszko $F_{1}$ ' } & 2008 & 26 & 16 & 35 & 39 & 116 \\
\hline & 2009 & 21 & 19 & 41 & 12 & 93 \\
\hline & 2010 & 15 & 24 & 43 & 11 & 93 \\
\hline \multirow{3}{*}{ 'III A F ${ }_{1}$ ' } & 2008 & 24 & 9 & 37 & 46 & 116 \\
\hline & 2009 & 22 & 24 & 40 & 15 & 101 \\
\hline & 2010 & 14 & 23 & 30 & 15 & 82 \\
\hline \multirow{3}{*}{ 'Ondraszek' } & 2008 & 25 & 8 & 37 & 26 & 96 \\
\hline & 2009 & 24 & 22 & 40 & 11 & 97 \\
\hline & 2010 & 13 & 24 & 30 & 15 & 82 \\
\hline \multirow{3}{*}{ 'Hubal' } & 2008 & 27 & 15 & 35 & 34 & 111 \\
\hline & 2009 & 23 & 17 & 34 & 13 & 87 \\
\hline & 2010 & 14 & 24 & 40 & 15 & 93 \\
\hline \multirow{3}{*}{ 'Talon' } & 2008 & 25 & 10 & 41 & 19 & 95 \\
\hline & 2009 & 21 & 14 & 46 & 14 & 95 \\
\hline & 2010 & 20 & 20 & 38 & 11 & 89 \\
\hline
\end{tabular}

${ }^{*}$ See Tab. $2,{ }^{* *}$ vegetation period was calculated from sowing date

dry and optimal. Index lower than 1.0 means deficiency of precipitation. Podleśny (2009) pays attention, that in our climate, influence of the water factor on the yield of plants is larger than thermal factor. He regards that the deliberations about the influence of weather conditions on crop plants yielding should be based mainly on analysis of the distribution of precipitation and the rate of Sielianinow's hydrothermal index. The value of climatic indicators included in Tab. 2 showed, that in 2008 in stage 1 and 2 (planting until beginning of flowering and beginning of flowering until beginning of fruits setting) very dry conditions were appeared. As a result of it the irrigation of plants were done. During stage 3 (beginning of fruits setting till beginning of ripening) relatively humid, and stage
4 (beginning of ripening till harvest) relatively dry conditions were observed. In the 2009 year two first stage were characterized by excessively high humidity (very humid and extremely humid), however stage 3 and 4 occurred relatively dry and dry 2010 year was characterized by extremely humid stage 1, relatively dry stage 2 and relatively humid stage 3 and 4 .

The length of vegetative period was strongly diversified in years of investigation(Tab. 3). The examined cultivars needed 13-28 days on average to the appearance of the first flowers. The second stage (from the beginning of flowering till beginning of fruits setting) lasted from 8 up to 25 days. The third stage was the longest. Fruits needed from 23 up to 46 days for ripening. The fourth stage was 
the most diversified for each cultivars. It was possible to harvest 'Rejtan' cultivar in 2009 already after 7 days from the beginning of ripening, and the 'III AF' line needed as many as 46 days in 2008 for achieving the full maturity. A course of the weather affected the duration of individual developmental stages (Tab. 1 to 3 ). These results are confirmed by Podleśny (2009) research, who noticed that length of developmental stages of the faba bean depended mainly on an amount and a distribution of precipitation.

Marketable yield of examined cultivars (average for three years) varied from $0.81 \mathrm{~kg}$ at the 'Hetman' to 3.88 $\mathrm{kg}$ at the 'Ondraszek'. Obtained yield was adequate to those received by Kacjan Maršic et al. (2005) in Slovenia. Authors examined the influence of various climatic condition on fruit yield and quality of 10 determine tomato cultivars.

The dependence of total and marketable yield (Tab. 4 and 5) and the course of weather parameters during vegetation clearly showed, that cultivar was the crucial determining yielding factor. The studies of Rożek et al. (2011) showed that in spite of significantly higher yield observed in the year 2009 compared to yield in 2010, cultivar was the factor determining yielding level. Every year ' Dyno $\mathrm{F}_{1}$ ' was the highest-yielding cultivar, whereas 'Benito $\mathrm{F}_{1}$ ' was the lowest one. Todorov and Pevicharova (2003) reported that hybrid tomato cultivars showed higher variation of fruit yield, good adaptability, high yield potential and good quality compared to common cultivars. In our investigation such relations weren't being observed.

Depending on hydrothermal conditions during succeeding developmental stages yield of tomato cultivar varied (Tab. 1 to 5). Comparing the course of the weather in individual developmental stages it was noticed, that for the best cropping 'Ondraszek' cultivar (the highest marketable yield) the course of hydrothermal conditions was a little bit more beneficial than in case of the 'Hetman', which had the lowest marketable yield. At the Hetman cultivar the third stage, in which fruits developed, lasted Tab. 4. Total yield (kg per plant)

\begin{tabular}{cccc}
\hline Cultivar & 2008 & 2009 & 2010 \\
\hline 'Sokal F' & $6.02 \mathrm{a}-\mathrm{d}$ & $6.37 \mathrm{a}-\mathrm{d}$ & $3.34 \mathrm{ab}$ \\
\hline 'Batory F'' & $5.97 \mathrm{a}-\mathrm{d}$ & $6.77 \mathrm{a}-\mathrm{d}$ & $5.73 \mathrm{a}-\mathrm{d}$ \\
'Rejtan F'' & $7.66 \mathrm{~b}-\mathrm{d}$ & $9.43 \mathrm{~cd}$ & $5.69 \mathrm{a}-\mathrm{d}$ \\
'Hetman' & $4.99 \mathrm{a}-\mathrm{c}$ & $5.77 \mathrm{a}-\mathrm{d}$ & $1.94 \mathrm{a}$ \\
'Luban'' & $5.54 \mathrm{a}-\mathrm{d}$ & $7.09 \mathrm{~b}-\mathrm{d}$ & $6.24 \mathrm{a}-\mathrm{d}$ \\
'Babinicz' & $3.94 \mathrm{ab}$ & $5.73 \mathrm{a}-\mathrm{d}$ & $3.74 \mathrm{ab}$ \\
'Awizo F' & $5.86 \mathrm{a}-\mathrm{d}$ & $6.44 \mathrm{a}-\mathrm{d}$ & $6.97 \mathrm{~b}-\mathrm{d}$ \\
'Mieszko F' & $6.19 \mathrm{a}-\mathrm{d}$ & $4.95 \mathrm{a}-\mathrm{c}$ & $4.74 \mathrm{a}-\mathrm{c}$ \\
'III A F'' & $5.58 \mathrm{a}-\mathrm{d}$ & $7.87 \mathrm{~b}-\mathrm{d}$ & $4.36 \mathrm{ab}$ \\
'Ondraszek' & $7.74 \mathrm{~b}-\mathrm{d}$ & $10.22 \mathrm{~d}$ & $4.71 \mathrm{a}-\mathrm{c}$ \\
'Hubal' & $4.75 \mathrm{a}-\mathrm{c}$ & $4.01 \mathrm{ab}$ & $3.19 \mathrm{ab}$ \\
'Talon' & $4.66 \mathrm{a}-\mathrm{c}$ & $6.90 \mathrm{a}-\mathrm{d}$ & $4.27 \mathrm{ab}$ \\
Mean & $5.74 \mathrm{~b}$ & $6.80 \mathrm{~b}$ & $4.58 \mathrm{a}$ \\
\hline
\end{tabular}

Note: Values in the same column followed by different letters are significantly different (LSD test, $p<0.05$ )
35-42 days, in which 15-20 days with precipitation. At the best cropping 'Ondraszek' cultivar this stage extended to 30-40 days in which 13-18 days with precipitation. Hydrothermal conditions in case of both cultivars in investigated years were similar, appropriately from 0.8 to 2.0 . It means that 'Ondraszek' cultivar reacts better to high and frequent precipitations. In the first developmental stage precipitation impacted the total and marketable yield, that means that more frequent precipitation and low were more favorable at this stage.

It was proved by calculated correlation coefficients (0.63 and 0.60$)$ and the value of $\mathrm{F}$ - statistic $(7.12,6.13)$, (Tab. 6 and 7 ).

Confirmation of the differential impact of the weather conditions, in the different stages, multiple regression equations were obtained. There were selected only these factors which had a statistically significant influence on the amount of total and marketable yield (Tab. 6 and 7). These equations show the quantitative effect of thermal and precipitation on crop yields.

In the second developmental stage (beginning of flowering - beginning of fruits setting), it turned out that the water needs were the most significant to tomato cultivar. The regression equation also confirmed the sum precipitation were statistically significant impact on total yield. The calculated value of correlation coefficients and F - statistics were smaller than in the other stages, but they were still significant $(R=0.52$, a $F=3.97)$. It can be stated that the weather factor was less significant impact on total yield than in the other stages and it was not important to amount of marketable yield.

In the third developmental stage (beginning of fruits setting) all meteorological factors were considered statistically significant effect on total and marketable yield. According to the obtained regression equation the number of days with precipitation had the most positive impact to yield.

Tab. 5. Marketable yield (kg per plant)

\begin{tabular}{cccc}
\hline Cultivar & 2008 & 2009 & 2010 \\
\hline 'Sokal F' & $3.12 \mathrm{~h}-\mathrm{k}$ & $3.86 \mathrm{j}-\mathrm{k}$ & $0.63 \mathrm{abc}$ \\
\hline 'Batory F' & $2.76 \mathrm{e}-\mathrm{j}$ & $3.01 \mathrm{~g}-\mathrm{j}$ & $2.11 \mathrm{a}-\mathrm{j}$ \\
\hline 'Rejtan F' & $3.43 \mathrm{i}-\mathrm{k}$ & $2.94 \mathrm{f}-\mathrm{j}$ & $0.79 \mathrm{a}-\mathrm{d}$ \\
\hline 'Hetman' & $1.05 \mathrm{a}-\mathrm{f}$ & $0.73 \mathrm{a}-\mathrm{d}$ & $0.33 \mathrm{a}$ \\
\hline 'Lubań' & $2.87 \mathrm{e}-\mathrm{j}$ & $2.40 \mathrm{c}-\mathrm{j}$ & $1.34 \mathrm{a}-\mathrm{h}$ \\
\hline 'Babinicz' & $1.43 \mathrm{a}-\mathrm{h}$ & $2.16 \mathrm{a}-\mathrm{j}$ & $1.51 \mathrm{a}-\mathrm{h}$ \\
\hline 'Awizo F' & $2.86 \mathrm{e}-\mathrm{j}$ & $2.58 \mathrm{~d}-\mathrm{j}$ & $1.29 \mathrm{a}-\mathrm{h}$ \\
\hline 'Mieszko F'' & $2.32 \mathrm{~b}-\mathrm{j}$ & $2.11 \mathrm{a}-\mathrm{j}$ & $1.00 \mathrm{a}-\mathrm{e}$ \\
'III A F'' & $2.72 \mathrm{e}-\mathrm{j}$ & $1.01 \mathrm{a}-\mathrm{e}$ & $1.17 \mathrm{a}-\mathrm{g}$ \\
\hline 'Ondraszek' & $4.79 \mathrm{k}$ & $4.83 \mathrm{k}$ & $1.34 \mathrm{a}-\mathrm{h}$ \\
\hline 'Hubal' & $1.50 \mathrm{a}-\mathrm{h}$ & $1.57 \mathrm{a}-\mathrm{i}$ & $0.44 \mathrm{ab}$ \\
\hline 'Talon' & $2.28 \mathrm{~b}-\mathrm{j}$ & $3.55 \mathrm{jk}$ & $1.55 \mathrm{a}-\mathrm{i}$ \\
Mean & $2.59 \mathrm{~b}$ & $2.56 \mathrm{~b}$ & $1.13 \mathrm{a}$ \\
\hline
\end{tabular}

Note: Values in the same column followed by different letters are significantly different (LSD test, $p<0.05$ ) 
Tab. 6. Total yield dependence on meteorological factors

\begin{tabular}{ccccccc}
\hline Stage & Regration equation & $\mathrm{R}^{2}$ & $\mathrm{R}$ & $\mathrm{F}$ & $\mathrm{p}$ & Est. err. \\
\hline $1^{*}$ & $\mathrm{y}_{\mathrm{o}}=6.72-0.03 \mathrm{P}+0.32 \mathrm{~L}$ & 0.40 & 0.63 & 7.12 & 0.0008 & 1.40 \\
2 & $\mathrm{y}_{\mathrm{o}}=6.34+0.05 \mathrm{P}$ & 0.27 & 0.52 & 3.97 & 0.016 & 1.55 \\
3 & $\mathrm{y}_{\mathrm{o}}=7.11-0.01 \Sigma \mathrm{t}-0.04 \mathrm{P}+0.45 \mathrm{~L}$ & 0.40 & 0.63 & 7.12 & 0.0008 & 1.40 \\
4 & $\mathrm{y}_{\mathrm{o}}=6.97+0.01 \Sigma \mathrm{t}$ & 0.20 & 0.45 & 2.75 & 0.058 & 1.62 \\
$1 \div 4$ & $\mathrm{y}_{\mathrm{o}}=4.02-0.02 \mathrm{P}+0.23 \mathrm{~L}$ & 0.34 & 0.58 & 5.47 & 0.0038 & 1.48 \\
\hline
\end{tabular}

Stage: see Tab. 2, y - total yield, P - sum of precipitation, $\Sigma \mathrm{t}$ - sum of mean daily air temperature, L - number of days with precipitation, $\mathrm{R}$ - correlation, $\mathrm{F}$ - Fisher value, $\mathrm{p}$ - probability

Tab. 7. Marketable yield dependence on meteorological factors

\begin{tabular}{ccccccc}
\hline Stage & Regration equation & $\mathrm{R}^{2}$ & $\mathrm{R}$ & $\mathrm{F}$ & $\mathrm{p}$ & Est. err. \\
\hline $1^{*}$ & $\mathrm{y}_{\mathrm{h}}=3.10-0.02 \mathrm{P}+0.15 \mathrm{~L}$ & 0.36 & 0.60 & 6.13 & 0.002 & 0.96 \\
2 & Not significant impact of the weather on marketable yield & & & & & \\
3 & $\mathrm{y}_{\mathrm{h}}=3.53-0.63 \sum \mathrm{t}-0.58 \mathrm{P}+0.77 \mathrm{~L}$ & 0.38 & 0.61 & 6.47 & 0.0015 & 0.94 \\
4 & $\mathrm{y}_{\mathrm{h}}=2.20+0.72 \sum \mathrm{t}$ & 0.22 & 0.47 & 3.04 & 0.045 & 1.05 \\
$1 \div 4$ & $\mathrm{y}_{\mathrm{h}}=5.39-0.67 \mathrm{P}+0.40 \mathrm{~L}$ & 0.38 & 0.62 & 6.64 & 0.0013 & 0.94 \\
\hline
\end{tabular}

See Tab. 2 and 6, $\mathrm{y}_{\mathrm{h}}-$ marketable yield

The negative signs of the sums of precipitation and temperature indicate that too high temperatures and high precipitation have affected the total and marketable yield in the studied years $(\mathrm{R}=0.63 ; 0.61$ and F-statistic $=7.12$; 6.47).

In the last stage - fruit ripening and harvest, the regression analysis showed that only the thermal conditions determined the amount of the total and marketable yield. It seems that the thermal conditions influenced on the marketable yield more than the total yield $(\mathrm{R}=0.45 ; 0.47$ and F- statistic $=2.75 ; 3.04$ ).

Taking into account the growing seasons in 2008-2010 the amount of yield was inversely proportional to the sum of precipitation, and directly proportional to the number of days with precipitation. It means that tomato reacted positively on frequent but low precipitation.

\section{Conclusions}

A different sensitivity of examined tomato cultivars to the course of weather conditions was stated. 'Ondraszek' cultivar gets the highest marketable yield in all years of investigation what indicate that it is the most adaptated to variable weather conditions and cultivars 'Hetman', 'Hubal' and 'Babinicz' were least adaptated and yielded the lowest. Analysis of the influence of weather condition on total and marketable yield of twelve determine tomato cultivars showed that the sum and distribution of precipitation were decisive. High precipitations decreased total and marketable yield, whereas frequent and lower influenced favorable. Since from the third stage, i.e. the beginning of fruits setting to the beginning of ripening a larger impact of meteorological factors on marketable than total yield had been observed. In the fruits ripening stage a beneficial effect on marketable yield of only a sum of temperatures was stated.

\section{References}

Abdul-Baki AA, Stommel JR, Watada AE, Teasdale JR, Morse $\mathrm{RD}$ (1996). Hairy vetch mulch favorable impact yield of processing tomatoes. HortSci 31(3):338-340.

Bandurska H, Krzyszkowska J, Moliński K, Zielezińska M (2011). A method of early selection of cucumber genotypes insensitive to chilling based on data mining. Acta Sci Pol, Hortum Cultus 10(2):225-233.

Bokwa A, Skowera B (2009). Extreme pluvial conditions in Cracow and its surroundings in the years 1971-2005. Acta Agroph 167, 13(2):299-310.

Kacjan Maršić N, Oswald J, Jakše M (2005). Evaluation of ten cultivars of determinate tomato (Lycopersicum esculentum Mill.), grown under different climatic conditions. Acta Agric Slovenica 85(2):321-328.

Kalbarczyk R (2006). Time and spatial distribution of agrotechnical dates and phonological stages of cucumber in western Poland. Acta Sci Pol, Hortum Cultus 5(2):51-68.

Kalbarczyk R (2010). Climatic risk of field cultivation of cucumber (Cucumis sativus L.) in Poland. Not Bot Horti Agrobo 38(3):157-168.

Kałużewicz A, Krzesiński W, Knaflewski M, Lisiecka J, Spiżewski T, Frąszczak B (2010). The effect of temperature on the broccoli field and length of the period from head initiation to harvest. Acta Sci Pol, Hortum Cultus 9(3):167-174.

Konys E (1990). Variation in the cropping outdoor tomatoes in relation to atmospheric conditions and cultivation methods. Roczniki Akademii Rolniczej w Poznaniu, Ogrodnictwo 217(18):32-52.

Kossowska-Cezak U, Martyn D, Olszewski K, KopaczLembowicz M (2000). Meteorology and climatology, measurements, observations, studies., PWN, 259 p.

Licznar - Maleńczuk M (2004). Relationship between air 
temperature and phenological phases the beginning of the growing season and blooming period of two apple cultivars in Wrocław area. Acta Sci Pol, Hortum Cultus 3(1):25-36.

Podleśny J (2009). Effect of amount and distribution of precipitation during vegetation on growth, development and yielding of determinate and traditional faba bean varieties. Acta Agroph 14(2):413-425.

Rożek E, Nurzyńska-Wierdak R, Kosior M (2011). Quality and structure of single harvest tomato fruit yield. Acta Sci Pol, Hortorum Cultus 10(3):319-329.

Samborski AS (2006). Extreme temperature during interphase periods of winter wheat in the Zamosc region. Acta Agroph $8(2): 481-488$.

Skowera B, Kołodziej J (2003). The influence of pluviothermal factors on the yield of oats in the Orava-Nowy Targ Basin. Biul IHAR, Radzików 229:185-192.
Skowera B, Sękara A, Jędrszczyk E, Poniedziałek M, Dziamba $S_{z}$ (2007). Influence of meteorological conditions on the vegetation course of chickpea (Cicer arietinum L.) Acta Agroph 9(3):767-783.

Skowera B, Wojkowski J (2003). Changes in hydrothermal conditions in Poland in period 1931-1990. Studia Geograficzne 75. Wrocław, Wyd UW 262-267 p.

Todorov T, Pevicharova G (2003). Agrobiological and chemical evaluation of foreign determinate tomatoe cultivars. Res Nati Center for Agrarian Acience in Bulgaria, Sofia 40(5):457461.

Voican V, Lãcãtus V, Tãnãsescu M (1995). Growth and developmental of tomato plants related to climatic conditions from some areas of Romania. Acta Hort 412:355-365. 